\title{
TITLE:
}

\section{The Structure of Rice Production in Japan and Taiwan}

\author{
AUTHOR(S):
}

Fujiki, Hiroshi

\section{CITATION:}

Fujiki, Hiroshi. The Structure of Rice Production in Japan and Taiwan. KIER Discussion Paper 1997, 475

ISSUE DATE:

1997-12

URL:

http://hdl.handle.net/2433/129492

RIGHT: 


\title{
The Structure of Rice Production in Japan and Taiwan*
}

\author{
Hiroshi FUJIKI**
}

\section{Kyoto Institute of Economic Research,}

Kyoto University

Sakyo, Kyoto, 606-01, Japan

* Forthcoming to Economic Development and Cultural Change.

**This paper is a revised version of a part of my dissertation ( "A Study of Japanese Ricemarket Liberalization” [Ph.D.diss., University of Chicago, 1993]). I thank my thesis advisers; Yair Mundlak, Nancy Stokey and especially D. Gale Johnson who suggested the original ideas shown in this paper. I thank Chaw-hisa Tu for providing me with Taiwanese data and useful discussion on the Taiwanese economy. I am grateful to two anonymous referees for their helpful comments on the earlier version of this paper. 


\title{
The Structure of Rice Production in Japan and Taiwan
}

\author{
Hiroshi Fujiki \\ Kyoto Institute of Economic Research, Kyoto University
}

\section{Introduction}

This paper points out the failure of Japanese agricultural policy through an international comparison with Taiwanese agricultural policy. More specifically, the paper focuses on a comparison between Taiwanese rice production costs and those in the Non-Hokkaido region of Japan. There are many similarities between Taiwanese rice production and rice production in the Non-Hokkaido region of Japan; the farm size distribution, the variety of rice produced, and the degree of mechanization. It is also well known that the average cost of Japanese rice production decreases with farm size, as Hayami and Kawagoe for example, have shown. ${ }^{1}$ But Taiwanese rice production costs remain almost constant with respect to the scale of operation as Kuroda has confirmed. ${ }^{2}$ This paper argues that differing the government policies throughout the process of mechanizing rice production in these two very similar economies is one of the major reasons why we find such a difference in the cost structure of production. The Taiwanese government encourages contract farming, and succeeded in separating the land 
owner and the tiller. On the other hand, the Japanese government has encouraged large scale tenant farming since 1970, and particularly since 1980, but could not achieve this objective due to inconsistent policies to restrain the separation of land owner and the tiller. Given the unsatisfactory results of Japanese agricultural policy which has focused large scale tenancy farming, the introduction of efficient contract farming would be another beneficial policy option for Japanese rice production in the Non-Hokkaido region.

The organization of this paper is as follows. Section II shows some statistical evidence that justifies my assertion. Section III reports the results of quantitative analysis. Section IV concludes the paper with some policy implications.

\section{Some Statistical Evidence}

The Japanese and Taiwanese economies have many characteristics in common. In both economies the farm size distribution is skewed to the left, and part-time farm households are prevalent after the success of industrialization. Other similarities are found in the variety of rice produced, price supports, farmland regulations, and post World War II farmland reforms.

The major objective of land reform laws were to prevent the concentration of farmland towards a small number of absentee landlords as was often the case with the rural villages in Japan in the 1940s. The 1952 Japanese Agricultural Land Law stressed the principle that "farmland should be owned by those who actually cultivate it." The law imposed the upper limit on the ownership of farmland (3 ha 
in the Non-Hokkaido regions and 12 ha in the Hokkaido region), and kept the rent on a low level to help small scale tenant farmers. The law also determined that in principle landlords could not terminate land lease contract apart from the case where their tenants refused to pay rent for no reason. In Taiwan, the 194937.5 Percent Rent Reduction Act, the sale of public land, and the 1953 Land-to-the-tiller Act played the same role as the 1952 Japanese Agricultural Law did. As a result, the land lease contract became uncommon in both Japan and Taiwan, unlike in many other countries in Asia, North America, and Europe, and we found huge number of small scale owner-tiller farms in those two economies..

Both Japanese and Taiwanese land reforms were believed to be the most successful reforms ever taken in anywhere in the Asian countries, although they were guided by the American strategies against possible communist revolution. ${ }^{3}$ Reflecting those farmland regulations, the farm size distribution in Taiwan and the Non-Hokkaido region of Japan is almost identical even in 1985 as can be seen in Table 1.

However, there are many important differences between these two economies: the price level for rice, the rice production costs, and in particular, the ownership of machinery. Table 2 shows the area of rice harvest per machine in both economies. ${ }^{4}$ The Japanese statistics are for rice producing farms only, but the Taiwanese statistics are for machines held by all farm households, therefore the area of rice harvest per machines in Taiwan could be underestimated. Nonetheless, the average tractor in Taiwan works more than ten times as large an area as does the average tractor in Japan. Table 2 shows that even in the Hokkaido region of 
Japan, where large scale farming prevails for historical reasons as can be seen in Table 1, the average tractor in Taiwan works more than twice as large an area. This observation does not simply reflect the fact that Taiwanese farms use labor intensive techniques. By 1990, 98 percent of rice production was accomplished by machinery in Taiwan. Moreover, as can be seen in Table 3, in 1990, Taiwanese rice production required farmers to spend 238 hours in 1 ha of paddy field on average, while Japanese farmers in the Non-Hokkaido region spent 456 hours in 1 ha of paddy on average, and throughout the process of economic development, Taiwanese farmers have worked shorter hours than Japanese farmers. ${ }^{5}$

In short, Taiwanese farms utilize a relatively small number of machines more efficiently than Japanese farms in the Non-Hokkaido region, given an almost identical farm size distribution. This fact could be explained by Taiwanese governmental policy.

The Taiwanese government encouraged the mechanization of farms by organizing "custom farming" teams, which were groups of young and able farmers who purchased machinery and worked for those who did not have it. ${ }^{6}$ As a result, small land owners were encouraged to turn over their land to full-time farm households and received non-farm job opportunities. Readers might wonder if the same division of labor could have been achieved through the land lease contract. However, the Taiwanese government did not abolish the 37.5 Percent Rent Reduction Act, therefore the production of rice based on tenant farming was not a profitable business. Moreover, the 37.5 Percent Rent Reduction Act essentially determined that the landlords could not terminate the land lease contract in most 
cases, therefore farmers were not willing to lend their land. Hence Taiwanese government did their best to convince farmers that the contractual farming and custom farming were not subject to the provisions of the 37.5 Percent Rent Reduction Act. $^{7}$ For example, the Agricultural Development Statue in 1973 stressed that the contractual farming system was not regarded as a tenancy system. In 1983, the 37.5 Percent Rent Reduction Act was amended to give entrusted farming and custom farming a stronger legal basis. Those policies were consistent with the idea of maintaining the social values of small family farm while compensating for its economic weakness through governmental and co-operative actions. $^{8} \quad$ As a result, despite the fact that the farmland market did not work well, Taiwanese farms achieved efficient production of rice by the custom farming without changing the farm size distribution. Table 4 shows that in 1990, 77 percent of filed preparation, 72 percent of transplanting, and 83 percent of harvesting were done by custom farming team.

On the other hand, Japanese governmental policy after the revision of the Agricultural Land Law in 1970, and in particular the 1980 Farmland Utilization Promotion Law, was aimed at concentrating farm land towards relatively large scale farms via land lease agreements. This objective was not successfully achieved. One reason for this failure was that the Japanese government could not give up the owner-tiller principle discussed in the 1952 Agricultural Land Law completely as Honma points out. ${ }^{9}$ Moreover, other factors which raised the transaction cost of land lease contracts, including the scattered ownership of irregularly shaped paddies and favorable treatment of the inheritance tax for the owner-tiller, make it 
difficult to popularize land lease contracts. Therefore, small farm owners have tried to cultivate their own paddies while exploiting the merits of being an ownertiller and trying buy their own machine. The artificially elevated price of rice and the increase in non-farm income has helped their desire come true. As a result, the Japanese counterpart to custom farming, "contract farming," is not as common as it is in Taiwan, as can be seen in Table 4. "Contract farming" in Japan usually means that the larger farms, agricultural cooperative associations, or Agricultural Production Organizations take care of particular stages of rice production using machinery for the sake of other farms. Note that the Japanese contract farming is based on the bilateral agreement between the parties who want to use their machines efficiently and the farms who find it difficult to conduct some stages of rice production by themselves for some reason. Since such an opportunities are scattered over the rural communities, it is hard to match the demand for contract farming with the supply of contract farming. It is clear in Table 4 that most of the Japanese farms in the Non-Hokkaido regions do not utilize contract farming. Therefore, given the inactive farmland market, excessive investment to the machines leads to the observation that the machine cost, labor cost, and primary cost (total cost of production of rice minus by product) per 1 ha of paddy decreases with farm size as can be seen in Table 5 .

It has been suggested that the promotion of large-scale farming is one of the most promising ways to achieve efficient rice production in the Non-Hokkaido region of Japan, but there is no way to compete with the large-scale farming in the U.S., where 100 ha rice farms are typical. I argue that although Japanese rice 
production may never occur at the large scale of U.S. farms, Japanese farms in the Non-Hokkaido region could be at least as efficient as Taiwanese farms via contract farming. This is because the two economies have many things in common, apart from the fact that small Japanese farms invests too much in agricultural machines. I shall further argue that contract farming, in addition to the large scale tenancy system, is one important way to restore the efficiency of Japanese rice production, and I will show some evidence to support my argument in the next section.

\section{Some Quantitative Evidence}

\section{A. Basic Results}

Many Japanese researchers point out that the introduction of machines, whose speed of operation depends upon the size of paddies, into small and irregularly shaped paddies leads to a decreasing unit costs of rice production as the total area in rice cultivation in the cross section of farms increases, as we have seen in Table 5. This is because larger farms tend to use large, fast machines in relatively larger paddies. For example, Hayami and Kawagoe used Japanese national average data from The Kome Seisanhi Cyosa [Survey of Rice Production Costs] between 1951$55,56-60,61-65,66-70,71-75,76-80$ and $81-85$ to estimate the following equation ( 1 ):

$$
\ln (\text { Real Primary Cost of Production })_{i t}=a 0+a 1 \cdot \ln (\text { Output })_{i t}+e_{i t} \text {. }
$$

Here, subscript $i$ represents the farm size category of the grouped average data. For example, 0.3-0.5 ha farms, 0.5-1.0 ha farms, and so forth. Primary cost is the 
total rice production costs net of the value of by products. Output is measured by $\mathrm{kg}$ of brown rice unit. This specification assumes that the factor prices relevant for the rice production are constant within Japan. Therefore, cross sectionally, it is impossible to identify the effect of factor prices on the cost function. This assumption is reasonable given the situation where agricultural cooperatives dictate the sale of agricultural implements and materials used for the rice production. According to Hayami and Kawagoe, the cost elasticity of scale, a1, was 0.918 , $0.919,0.923,0.869,0.820,0.786$ and 0.774 respectively for the periods from $1951-55,56-60,61-65,66-70,71-75,76-80$ and $81-85$. That is, the cost elasticity of scale fell over time as Japan introduced larger machines. Hayami and Kawagoe argued that this was the result of a land market imperfection, because the efficient techniques used by the large-scale farms did not prevail on all farms.

In the previous section I pointed out that Taiwanese farms are as small as Japanese farms and subject to several regulations, but their mechanization was based on "custom farming" teams. In such a situation, neither small farm size nor farmland regulations can be the source of economies of scale if the argument of Hayami and Kawagoe is right; i.e., al should be close to one if we estimate equation ( 1 ) using Taiwanese data.

We will verify this conjecture by estimating equation ( 2 ):

$$
\ln (\text { Real Primary Cost of Production })_{i t}=a_{t}+a 1 \cdot \ln (\text { Output })_{i t}+e_{i t}, \quad \text { ( } 2 \text { ) }
$$

where $a_{t}$ shows the time effect in year $\mathrm{t}$ using grouped average data on farms with less than 0.5 ha, 0.5-0.75 ha, 0.75-1.0 ha, 1.0-1.5 ha, and more than 1.5 ha of rice cultivation between 1985-1991 as found in Taiwanese rice cost survey statistics. 
Japanese average data on the farms in the Non-Hokkaido region, where the farm size distribution is almost identical to that of Taiwan, from 1986-1991 in groups of farm size of less than 0.3 ha, 0.3-0.5 ha, 0.5-1.0 ha, 1.0-1.5 ha, 1.5-2.0 ha, 2.0-2.5 ha, 2.5-3.0 ha, 3.0-4.0 ha, 4.0-5.0 ha, and more than 5.0 ha of rice cultivation was used for the sake of comparison. ${ }^{10}$ My sample period is long enough to compare Taiwanese mechanized production and Japanese medium sized mechanized production. I first estimate equation ( 2 ) cross sectionally in each economy for every year, and then estimate the pooling model which utilizes all of the data to test the hypothesis that the parameters a1 and $a_{t}$ are constant over time. I also estimate a restricted model holding al constant over time while allowing $a_{t}$ to change. I further estimate a random effects model. The estimations use the square root of the sample size to compute each group mean as a weight. ${ }^{1}{ }^{1}$ The results are shown in Table 6.

For the Non-Hokkaido regions of Japan, cross sectional estimates of a1 are in the range of $0.73-0.78$, and those models explain about $99 \%$ of the variation in the real primary cost for each year. The pooling model that holds both a1 and $a_{t}$ constant over time yields an a1 estimate of 0.7569 . However, the F-value testing the constancy of a1 and $a_{t}$ over time is large enough for us to reject the pooling model. The model which restricts a1 to be constant over time but allows $a_{t}$ to vary yields an a1 estimate of 0.7555 . The F-value testing the constancy of a1 over time against the cross sectional model is 0.9237 , and we accept the null hypothesis of constant a1. The random effects model estimates a1 to be 0.7556 . The value of the LM test statistic is large enough for us to reject the null hypothesis of the 
pooling model compared to the random effects model at zero percentage point as the p-value shows. But the value of Hausman test statistic which compares the random effects model against the restricted model is too small to allow rejection of random effects model the as p-value shows.

Overall consideration suggests that the relevant model is the random effects model for the Non-Hokkaido region of Japan, and that a plausible value for a1 is 0.755. The results are consistent with those of Hayami and Kawagoe, and we do not find any significant structural changes in Japanese rice production after 1985.

For Taiwan, cross sectional estimates of equation (2) in each year are in the range of $0.97-1.03$, and those models explain about $99 \%$ of the variation in the real primary cost for each year. The estimates suggest that the Taiwanese rice production technology yields close to constant returns to scale. The Pooling model that holds both a1 and $a_{t}$ constant over time yields an a1 estimate of 0.9939 . However, the F-value testing the null hypothesis of constancy of a1 and $a_{t}$ is large enough for us to reject this pooling model at zero percent level of significance. The model which restricts a1 to be constant over time but allows $a_{t}$ to vary yields an a1 estimate of 1.0002. The F-value testing the restricted model versus the cross sectional model is 2.5678 , and I accept the null hypothesis of constancy of a1 over time only at the $4 \%$ level. The random effects model also suggests that a1 is 0.9996, but in the case of Taiwan, the statistically preferred model is the restricted model since the Hausman test statistic for the random effects model is large enough for us to reject the null hypothesis of the random effects model. The finding that the production technology of rice in Taiwan exhibits constant returns to scale is 
consistent with the results of Kuroda, who estimates a translog cost function using Taiwanese data from the years 1976-1993, and finds that the elasticity of cost with respect to scale is one.

In summary, given almost the same farm size distribution, Japanese rice production in the Non-Hokkaido region is characterized as exhibiting increasing returns to scale but the Taiwanese economy exhibits constant returns to scale. Since the source of increasing returns to scale in Japan is the inefficient usage of machines as we have seen in Table 5, it is reasonable to find that Taiwanese rice production, which utilizes the machinery efficiently though custom farming, exhibits constant returns to scale technology.

To check the robustness of my results shown in Table 6 , I show the results of regression equation (2) using total cost, which adds rent and capital interest to primary cost, rather than primary cost as a dependent variable following Hayami and Kawagoe. The results are summarized in Table 7. Although the estimates of a1 are slightly larger than those shown in Table 6 , the qualitative results are robust to the choice of cost measure.

\section{B. Results based on Agricultural Production Organizations data}

Readers might want to see the Japanese rice production costs under contract farming. To this end, recent Japanese statistics from Agricultural Production Organizations, which become available after 1991, are useful. An Agricultural Production Organization can be a joint production organization of farms, or a union of farms which works together on some particular stages of rice production on 
behalf of member farms. Therefore, the production costs of Japanese Agricultural Production Organizations are a good proxy for the cost of production via contract farming. Using data from Agricultural Production Organizations during the period from 1991-1994, we estimate equation ( 2 ) once again. For the sake of comparison, we estimate the same equation using Japanese farm data in the NonHokkaido region of Japan. The results are summarized in Tables 8 and 9. Note that the number of Agricultural Production Organizations surveyed to compile this statistics are not available, hence the estimations are done by OLS.

The Agricultural Production Organizations data yield cross sectional estimates for a1 in the range from $0.83-0.85$ by using primary cost, and in the range from $0.89-0.91$ by using total cost. The pooling model estimates holding both a1 and $a_{t}$ constant over time yield an a1 estimate of 0.8415 and the F-value of testing the null hypothesis of constancy of a1 and $a_{t}$ over time is small enough for acceptance of this null hypothesis for primary cost. The restricted model holding a1 constant but allowing $a_{t}$ to vary over time yields an al estimate of 0.8385 . The F-value testing the restricted model against the cross sectional estimates is 0.0562 , and we accept the null hypothesis of constancy of a1. The random effects model also suggests that a1 is 0.8409 , and the statistically preferred model is the random effects model since the Hausman test statistic is so small. The LM statistic also supports the pooling model. The overall results suggest that the value of a1 in the presence of contract farming is $0.83-0.84$ for the primary cost, although the estimates are smaller than one. The plausible value of a1 for the total cost is close to 0.90 , but the estimates are still smaller than one. 
Note that the results using farm data from 1991-1994 shown in Tables 8 and 9 suggest that the relevant model is the random effects model, and a plausible value for a1 is 0.764 using primary cost and 0.831 using total cost, which are almost the same as the estimate of a1 obtained from the 1985-1991 data.

In summary, we could not find evidence of constant returns to scale using data from Japanese Agricultural Production Organizations. However, the evidence suggests that the introduction of contract farming would help to restore the efficiency of rice production in the sense that it increases the value of a1 in equation ( 2 ). Therefore, I argue that it makes sense to expand contract farming in the Non-Hokkaido regions of Japan.

\section{Policy Implications}

The sustained efficiency in the rice production during the process of substituting machines for agricultural labor in Taiwan seems to be relevant for the NonHokkaido region of Japan. Small farm size per se will not be a source of inefficiency as long as the separation of owner and tiller can be achieved through machine sharing or contract farming. The Japanese government should change any legal or institutional treatments that have induced farmers to be owner-tillers as long as it is useful to reduce the rice production costs. The local agricultural committee, the agricultural cooperative associations, and local government can give the information on the demand and supply of contract farming as well as land market to every farmer. If the entry of joint stock companies in the agricultural production were allowed, those information would be very valuable. Such reform 
might result in the prevalence of both contract farming and land lease contract. However, contract farming is more flexible than land lease contract because farmers can choose the particular stages of production which they would like to ask someone to work for them. We may be able to restore the efficiency of production of rice in the Non-Hokkaido regions of Japan in each stage of the production of rice if we encourage the contract farming. At least we are sure that contract farming is one of the promising way to achieve the aim of policy, and we have no reason to stick to the large scale tenant system alone.

Given the acceptance of the GATT Uruguay Round accord, it is hard to imagine a situation where the Japanese government could set the domestic price of rice at an artificially high level at their will. The Japanese government sustained the high price of rice through the acreage control program, but the application of a uniform rate of acreage control independent of farm size is counterproductive given the huge disparity in the average cost of production with respect to farm size. If a reduction in the price of rice is necessary, the acreage control program per se is not compatible with this national objective. If it is still difficult to concentrate farm land towards large scale farms via land lease agreements, the Japanese government should also encourage contract farming in the Non-Hokkaido region, and reduce both the cost of production of relatively small farms and price of rice. 
TABLE 1

FARM SIZE DISTRIBUTION IN 1985

\begin{tabular}{|c|c|c|c|c|}
\hline \multicolumn{2}{|c|}{ Farm size } & Non-Hokkaido & Taiwan & Hokkaido \\
\hline 0 & -0.5 ha & $43.4 \%$ & $41.9 \%$ & \\
\hline 0.5 & - 1.0 ha & $27.7 \%$ & $30.7 \%$ & \\
\hline 0 & - 1.0 ha & & & $10.0 \%$ \\
\hline 1.0 & -2.0 ha & $20.6 \%$ & $20.1 \%$ & \\
\hline 2.0 & -3.0 ha & $5.4 \%$ & $4.7 \%$ & \\
\hline 1.0 & - 3.0 ha & & & $14.6 \%$ \\
\hline 3.0 & - 5.0 ha & $2.1 \%$ & $1.9 \%$ & $14.6 \%$ \\
\hline 5.0 & + ha & $0.4 \%$ & $0.6 \%$ & \\
\hline 5.0 & - 10.0 ha & & & $23.8 \%$ \\
\hline 10.0 & - 20.0 ha & & & $14.6 \%$ \\
\hline 20.0 & + ha & & & $12.8 \%$ \\
\hline Numb & er of Farms & $4,120,000$ & 771,000 & 109,000 \\
\hline
\end{tabular}


TABLE 2

THE AREA IN RICE HARVEST PER MACHINE

\begin{tabular}{l|cccc}
\hline \hline \multicolumn{1}{c|}{ Machine type } & $\begin{array}{c}\text { Non-Hokkaido } \\
(1990)\end{array}$ & $\begin{array}{c}\text { Taiwan } \\
(1990)\end{array}$ & $\begin{array}{c}\text { Hokkaido } \\
(1990)\end{array}$ & $\begin{array}{c}\text { All Japan } \\
(1990)\end{array}$ \\
\hline Tractor and power tillers & $0.53 \mathrm{ha}$ & $4.67 \mathrm{ha}$ & $2.11 \mathrm{ha}$ & $0.56 \mathrm{ha}$ \\
Power rice planters & $1.04 \mathrm{ha}$ & $11.30 \mathrm{ha}$ & $4.64 \mathrm{ha}$ & $1.10 \mathrm{ha}$ \\
Combines & $1.62 \mathrm{ha}$ & $28.18 \mathrm{ha}$ & $5.31 \mathrm{ha}$ & $1.71 \mathrm{ha}$ \\
\hline
\end{tabular}

Note: Power rice planters include less than 2, 2-4, and more than 6 row types. 
TABLE 3

\section{HOURS WORKED IN 1 HA OF PADDY FIELD}

\begin{tabular}{l|cccc}
\hline \hline \multicolumn{1}{c|}{ Year } & 1960 & 1970 & 1980 & 1990 \\
\hline Non-Hokkaido & n.a. & 1215 & 664 & 456 \\
Taiwan, 1st.crop & 864 & 844 & 394 & 238 \\
Hokkaido & 1463 & 909 & 433 & 287 \\
All Japan & 1729 & 1178 & 644 & 438 \\
\hline
\end{tabular}

Sources: The Kome Seisanhi Cyosa [Survey of Rice Production

Costs]; and Mao (1993), p.25. 
TABLE 4

COMPARISON OF THE AREA IN RICE CULTIVATION ON JAPANESE CONTRACT FARMS AND

TAIWANESE CUSTOM FARMS IN 1990

\begin{tabular}{lccc}
\hline \hline & $\begin{array}{c}\text { Field } \\
\text { cultivation }\end{array}$ & Transplant & Harvest \\
& $8.6 \%$ & $8.2 \%$ & $13.8 \%$ \\
Non-Hokkaido & $76.9 \%$ & $82.0 \%$ & $83.0 \%$ \\
Taiwan & & \\
\hline
\end{tabular}

Sources: The Agriculture Census 1990; and Mao (1993), p.26. 
TABLE 5

\section{MACHINE COST, LABOR COST AND PRIMARY COST IN 1 HA OF \\ PADDY FIELD}

(FARMS LARGER THAN 5.0 ha $=100)$

\begin{tabular}{lc|ccc}
\hline \hline \multicolumn{2}{c|}{ Farm size } & Machine cost & Labor cost & Primary cost \\
\hline 0 & -0.3 ha & 192 & 224 & 194 \\
0.3 & -0.5 ha & 184 & 211 & 179 \\
0.5 & -1.0 ha & 174 & 181 & 159 \\
1.0 & -1.5 ha & 156 & 153 & 139 \\
1.5 & -2.0 ha & 142 & 137 & 127 \\
$2.0-2.5$ ha & 130 & 126 & 119 \\
2.5 & -3.0 ha & 134 & 123 & 120 \\
3.0 & -4.0 ha & 125 & 118 & 114 \\
$4.0-5.0$ ha & 111 & 102 & 103 \\
$5.0+$ ha & 100 & 100 & 100 \\
\hline
\end{tabular}

Sources: The Kome Seisanhi Cyosa [Survey of Rice Production Costs] 1985-1991. 
TABLE 6

RESULTS OF REGRESSION EQUATION (2): JAPANESE FARM DATA VERSUS TAIWANESE FARM DATA

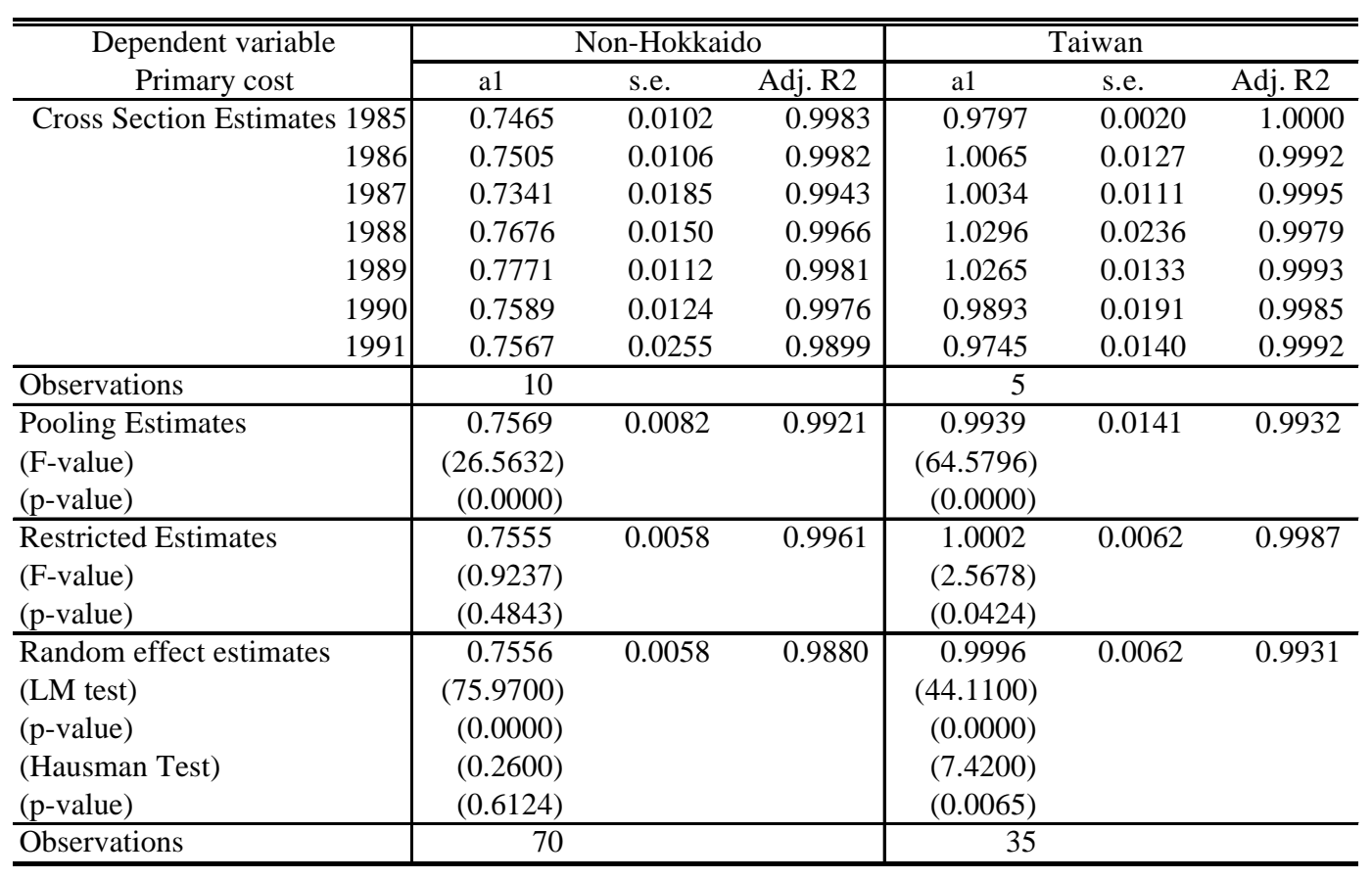


TABLE 7

RESULTS OF REGRESSION EQUATION (2): JAPANESE FARM DATA VERSUS TAIWANESE FARM DATA

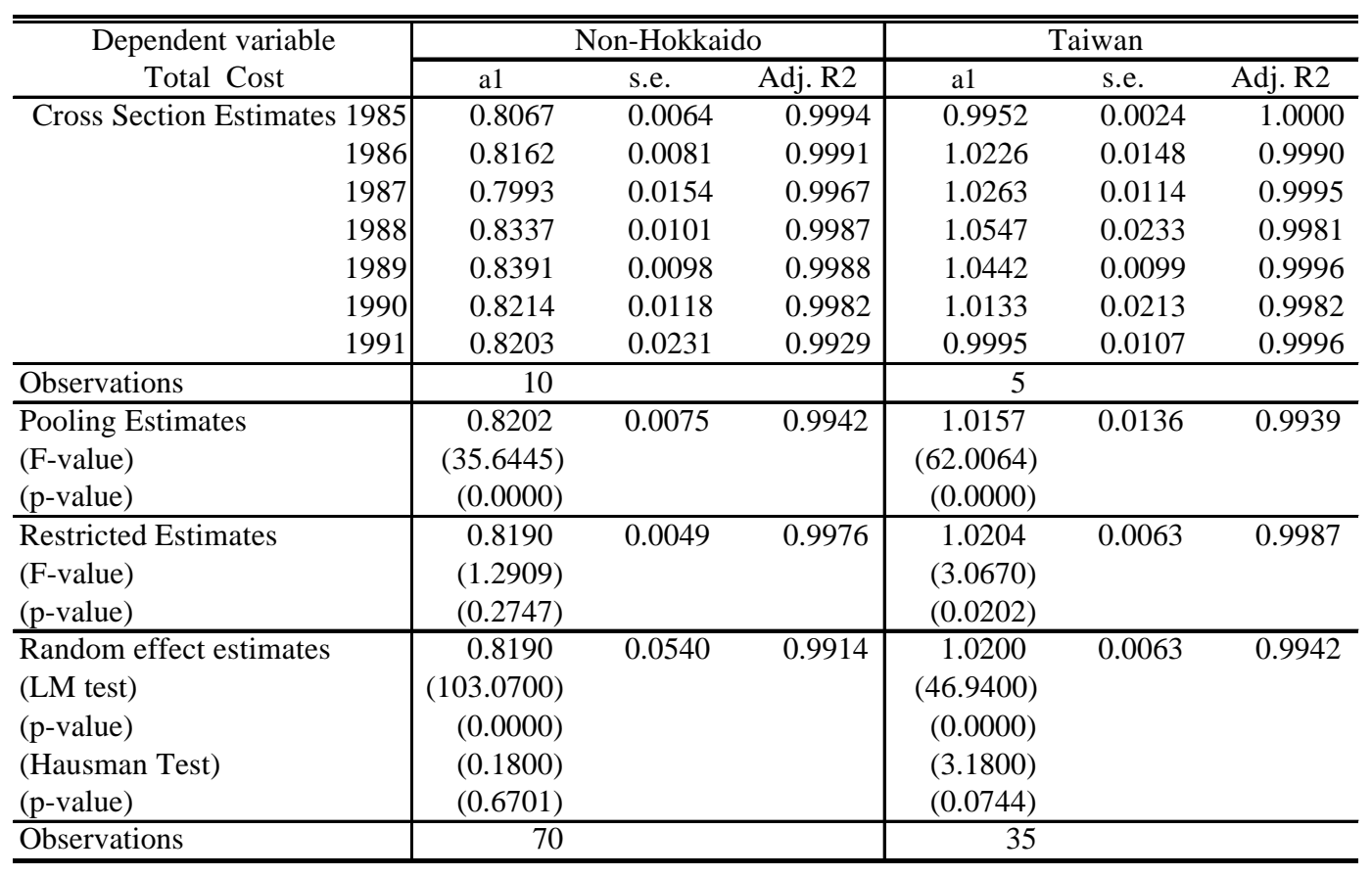


TABLE 8

RESULTS OF REGRESSION EQUATION (2): JAPANESE AGRITULTURAL PRODUCTION ORGANIZARTION DATA

VERSUS JAPANESE FARM DATA

\begin{tabular}{|c|c|c|c|c|c|c|}
\hline \multirow{2}{*}{$\begin{array}{c}\text { Dependent variable } \\
\text { Primary cost }\end{array}$} & \multicolumn{3}{|c|}{ "Agricultural Production Organizaions } & \multicolumn{3}{|c|}{ "Non-Hokkaido Farms } \\
\hline & a1 & s.e. & Adj. R2 & a1 & s.e. & Adj. R2 \\
\hline Cross Section Estimates 1991 & 0.8521 & 0.0597 & 0.9806 & 0.7610 & 0.0172 & 0.9954 \\
\hline 1992 & 0.8453 & 0.0490 & 0.9867 & 0.7602 & 0.0149 & 0.9966 \\
\hline 1993 & 0.8242 & 0.0780 & 0.9651 & 0.7592 & 0.0169 & 0.9956 \\
\hline 1994 & 0.8331 & 0.0417 & 0.9901 & 0.7760 & 0.0083 & 0.9990 \\
\hline Observations & 5 & & & 10 & & \\
\hline Pooling Estimates & 0.8415 & 0.0262 & 0.9819 & 0.7631 & 0.0081 & 0.9956 \\
\hline (F-value) & $(1.4219)$ & & & $(11.1701)$ & & \\
\hline (p-value) & $(0.2838)$ & & & $(0.0000)$ & & \\
\hline Restricted Estimates & 0.8385 & 0.0267 & 0.9813 & 0.7645 & 0.0070 & 0.9968 \\
\hline (F-value) & $(0.0562)$ & & & $(0.3455)$ & & \\
\hline (p-value) & $(0.9818)$ & & & $(0.7926)$ & & \\
\hline Random effect estimates & 0.8409 & 0.0266 & 0.9828 & 0.7643 & 0.0070 & 0.9939 \\
\hline (LM test) & $(0.2200)$ & & & $(14.7800)$ & & \\
\hline (p-value) & $(0.6390)$ & & & $(0.0001)$ & & \\
\hline (Hausman Test) & $(1.3700)$ & & & $(0.2400)$ & & \\
\hline (p-value) & $(0.2414)$ & & & $(0.6222)$ & & \\
\hline Observations & 20 & & & 40 & & \\
\hline
\end{tabular}


TABLE 9

RESULTS OF REGRESSION EQUATION (2): JAPANESE AGRITULTURAL PRODUCTION ORGANIZARTION DATA

VERSUS JAPANESE FARM DATA

\begin{tabular}{|c|c|c|c|c|c|c|}
\hline \multirow{2}{*}{$\begin{array}{c}\text { Dependent variable } \\
\text { Total Cost } \\
\end{array}$} & \multicolumn{3}{|c|}{ " Agricultural Production Organizaions } & \multicolumn{3}{|c|}{ Non-Hokkaido Farms } \\
\hline & a1 & s.e. & Adj. R2 & a1 & s.e. & Adj. R2 \\
\hline Cross Section Estimates 1991 & 0.9059 & 0.0181 & 0.9984 & 0.8295 & 0.0146 & 0.9972 \\
\hline 1992 & 0.8980 & 0.0251 & 0.9969 & 0.8298 & 0.0129 & 0.9978 \\
\hline 1993 & 0.8939 & 0.0480 & 0.9886 & 0.8235 & 0.0141 & 0.9974 \\
\hline 1994 & 0.8895 & 0.0267 & 0.9964 & 0.8387 & 0.0056 & 0.9996 \\
\hline Observations & 5 & & & 10 & & \\
\hline $\begin{array}{l}\text { Pooling Estimates } \\
\text { (F-value) } \\
\text { (p-value) } \\
\end{array}$ & $\begin{array}{c}0.8989 \\
(5.1996) \\
(0.0075) \\
\end{array}$ & 0.0167 & 0.9935 & $\begin{array}{r}0.8281 \\
(23.1125) \\
(0.0000) \\
\end{array}$ & 0.0079 & 0.9964 \\
\hline $\begin{array}{l}\text { Restricted Estimates } \\
\text { (F-value) } \\
\text { (p-value) } \\
\end{array}$ & $\begin{array}{c}0.8969 \\
(5.1996) \\
(0.0075) \\
\end{array}$ & 0.0144 & 0.9952 & $\begin{array}{c}0.8311 \\
(0.2684) \\
(0.8477) \\
\end{array}$ & 0.0059 & 0.9981 \\
\hline $\begin{array}{l}\text { Random effect estimates } \\
\text { (LM test) } \\
\text { (p-value) } \\
\text { (Hausman Test) } \\
\text { (p-value) } \\
\end{array}$ & $\begin{array}{c}0.8975 \\
(2.1700) \\
(0.1408) \\
(0.8100) \\
(0.3682) \\
\end{array}$ & 0.0144 & 0.9938 & $\begin{array}{r}0.8308 \\
(42.3100) \\
(0.0000) \\
(0.9900) \\
(0.3191) \\
\end{array}$ & 0.0059 & 0.9946 \\
\hline Observations & 20 & & & 40 & & \\
\hline
\end{tabular}




\section{Notes}

1. Hayami Yujiro and Toshihiko Kawagoe, "Farm Mechanization, Scale Economies, and Structural Change," in The Agricultural Development of Japan, ed. Yujiro Hayami and Saburo Yamada, (Tokyo: Tokyo University Press, 1991).

2. Kuroda Yoshimi, "Effects of R \& E Activities on Rice Production in Taiwan, 1976-1993," in Projections and Policy Implications of Supply and Demand of Rice in South Korea, Taiwan, Japan and U.S.A. (Final Report of the International Scientific Research Program of the Ministry of Education, Science and Culture, Japanese Government, 1997).

3 . King Russell, Land Reform (London: G. Bell and Sons Ltd., 1977).

4. So far I could not find any comprehensive study comparing the quality of machines used in those two economies. However, historically it is well known that most of Taiwanese farm machines were imported from Japan. See Francesca Bray, The Rice Economies: Technology and Development in Asian Societies. (Oxford: Basil Blackwell, 1986), esp. 59.

5. Mao Yu-kang, "Structure and Change in the Agriculture of Taiwan," In Agricultural Policy and U.S. - Taiwan Trade, ed. D. Gale. Johnson and Chi-ming Hou [Washington D. C.: The AEI Press, 1993] .

6. Mao, esp. 25-27.

7. Mao, Yu-kang. and Chaw-hisa Tu. "Current Agricultural Problems and 
Policies of Taiwan," in Agricultural Policy and U.S. - Taiwan Trade, ed. D. Gale. Johnson and Chi-ming Hou (Washington D. C.: The AEI Press, 1993).

8 . King, esp. 217.

9 . Honma Masayoshi, Nougyo-Mondai no Seiji-Keizaigaku [The Political Economy of Agriculture] (Tokyo: Nippon Keizai Shinbunsya, 1994). Chapter 6 of this book contains a brief review of Japanese Agricultural Policy.

10 . Taiwanese primary costs were deflated by the price index of payments made by the farmers for agricultural production inputs, and Japanese primary costs were deflated by the price index of rice.

11 . Only the total sample size to compute the group mean for each group of farm size are available in The Kome Seisanhi Cyosa [Survey of Rice Production Costs] 1985-1991. However, since the average data in the group of farm size for the Non-Hokkaido region and the Hokkaido region are available, I can estimate the sample size of the Non-Hokkaido region farms by solving simple linear programming. 